*ak FMIS View/Frint Document Cover Sheet tow

This document was retrieved from the Documentation and Records Manaqement (DRM) ISEARCH System. It is intended for Information only and may not be the most recent or updated version. Contact a Document Service Center (see Hanford Info for locations) if you need additional retrieval information.

Accession \#: D196037793

Document \#: SD-SNF-ATP-018

Title/Desc:

ACCEPTANCE TEST PROCEDURE FOR THE SNF CANISTERS SLUDGE DEPTH MEASUREMENT DEVICE

Pages: 18 


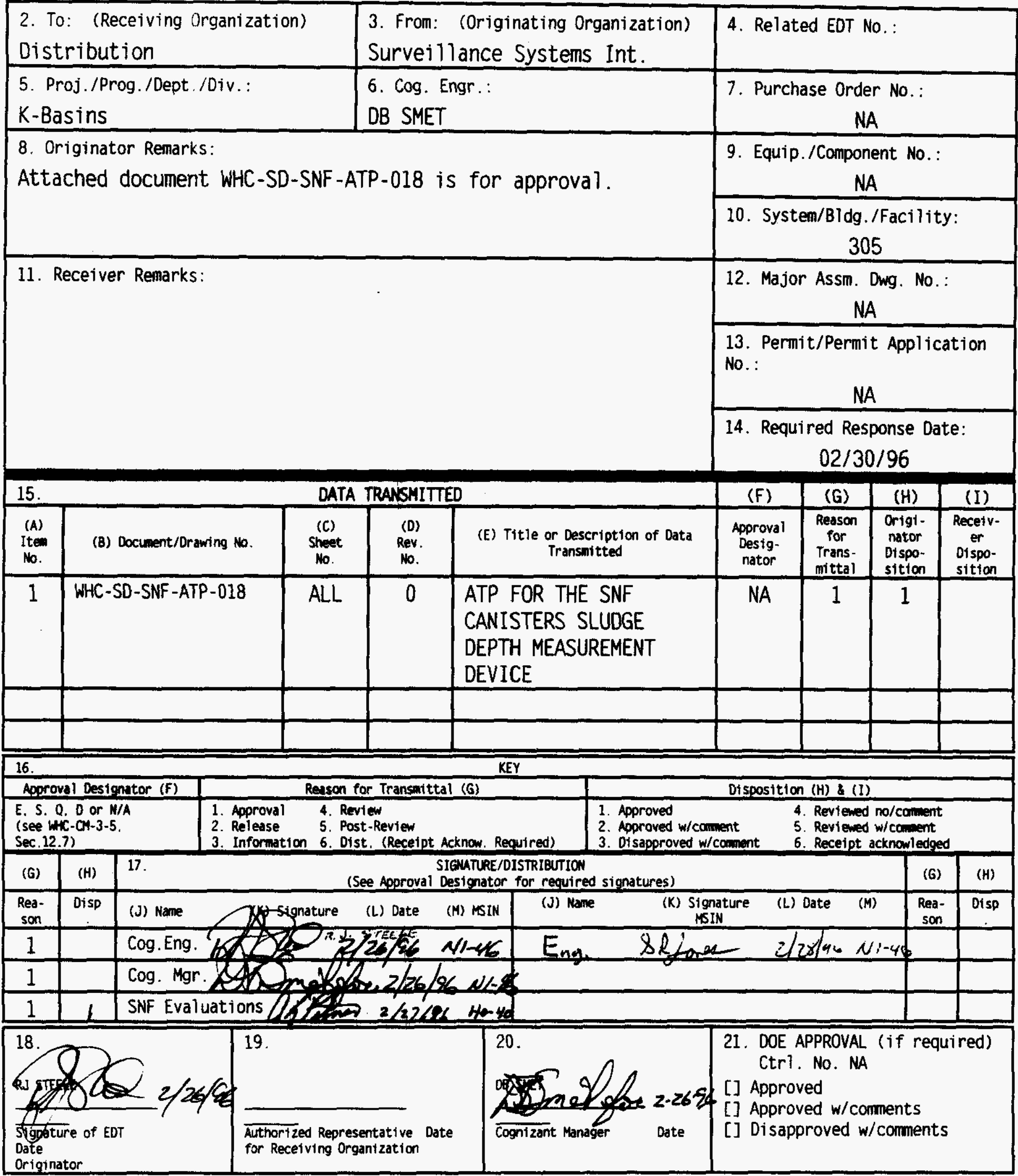

BD-7400-172-2 (04/94) GEF097 


\section{ACCEPTANCE TEST PROCEDURE (ATP) FOR THE SNF CANISTERS SLUDGE DEPTH MEASUREMENT DEVICE}

R. J. Steele

Westinghouse Hanford Company, Richland, WA 99352

U.S. Department of Energy Contract DE-AC06-87RL10930

EDT/ECN : 611287

Org Code: 74430

UC: 2020

B\&R Code: EW3135040

Charge Code: LB021

Tota1 Pages: 16

Key Words: Canister, Sludge. UT

Abstract:

This document outlines the steps required to properly document the acceptance testing of this prototypical device.

TRADEMARK DISCLAIMER. Reference herein to any specific comercial product, process, or service by trade neme, tradenark, manufacturer, or otherwise, does not necessarily constitute or imply its endorsement, recommendation, or favoring by the United States Government or any agency thereof or its contractors or subcontractors.

Printed in the United States of America. To obtain copies of this document, contact: WHC/BCS Document Control Services, P.0. Box 1970, Mailstop H6-08, Richiand WA 09352, Phone_(509) 372-2420: Fax (509) 376-4989.
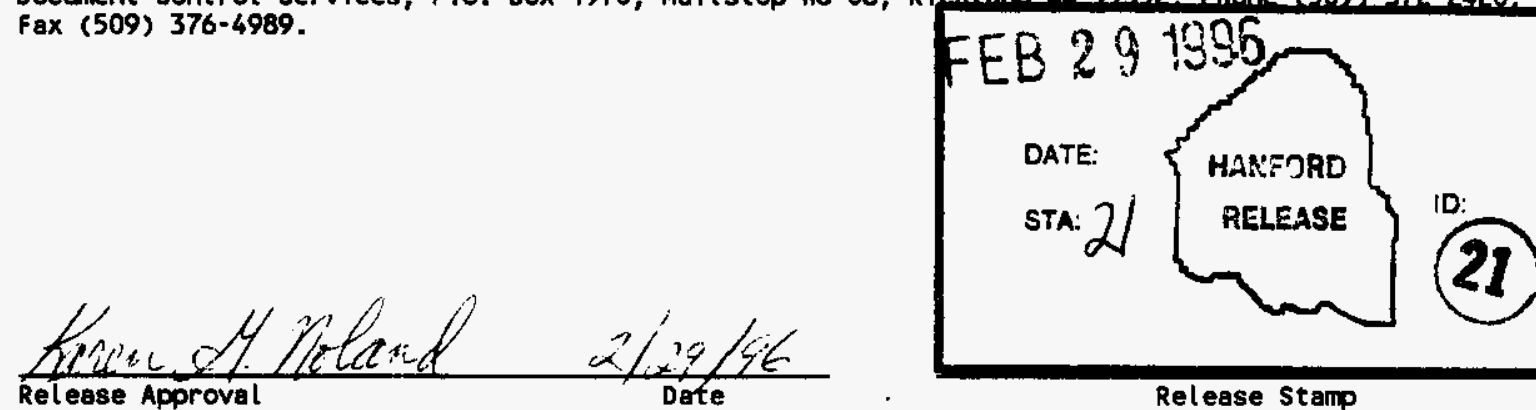


\section{ACCEPTANCE TEST PROCEDURE (ATP) FOR THE SNF CANISTERS SLUDGE DEPTH MEASUREMENT DEVICE}

Approval Designator: N/A

Robert J. Steele

Surveillance Systems Integration

February 2, 1996 


\section{TABLE OF CONTENTS}

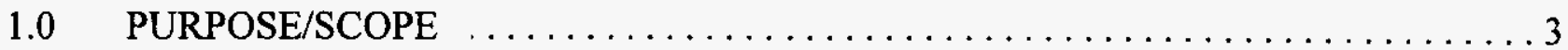

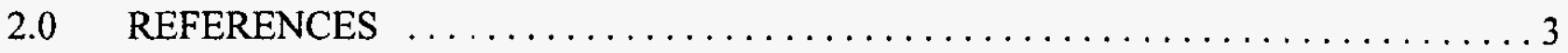

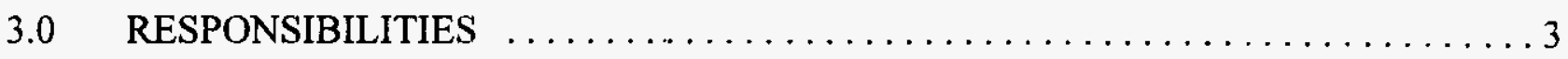

$3.1 \quad$ Surveillance Systems Integration (SSI) $\ldots \ldots \ldots \ldots \ldots \ldots \ldots \ldots \ldots \ldots \ldots \ldots$

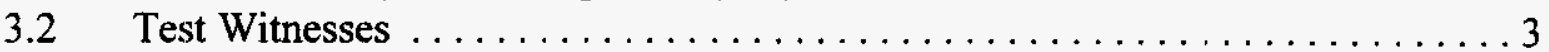



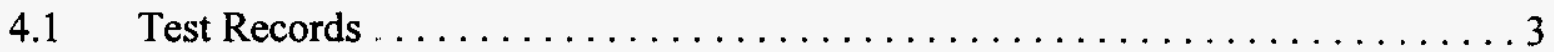

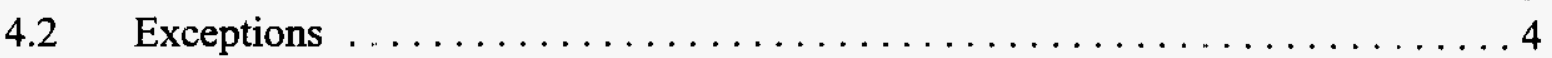

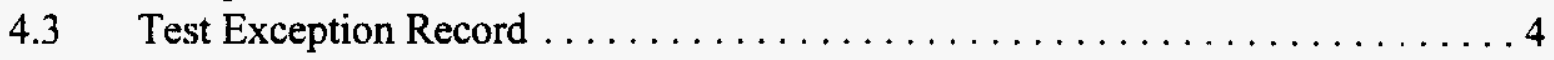

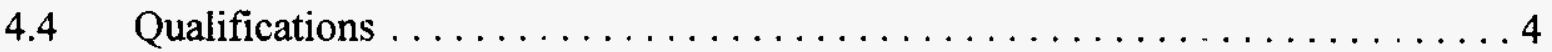

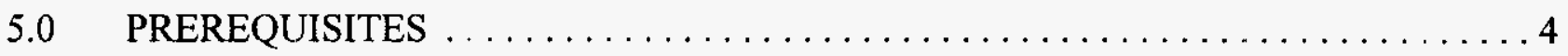

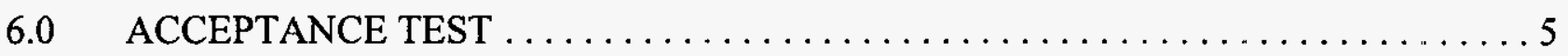

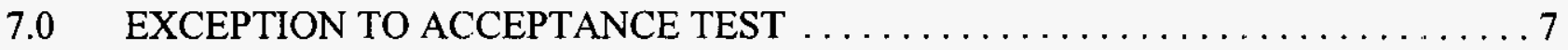

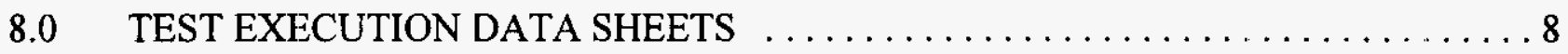

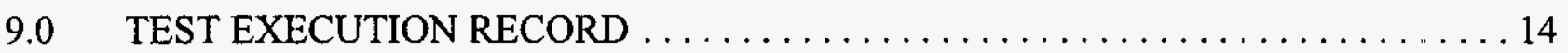

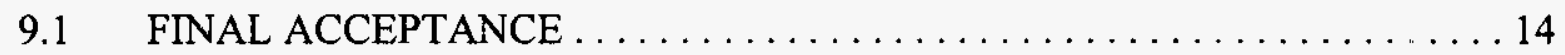

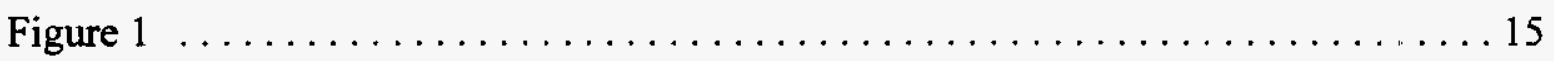




\section{ACCEPTANCE TEST PROCEDURE \\ OF THE \\ SNF CANISTERS SLUDGE DEPTH MEASUREMENT DEVICE}

\subsection{PURPOSE/SCOPE}

This Acceptance Test Procedure (ATP) provides step by step instructions for the functional testing of a device that measures the accumulated sludge in spent nuclear fuel storage canisters using a specially designed Ultrasonic Test (UT) device. Predetermined points (as shown in Figure 1) within the Mark II canisters will be used to measure the depth of the sludge. This data will be compared to values measured with a caliper to determine the accuracy of the device and will aid in system validation. The final acceptance of this device will be based upon satisfactory completion of this test.

\subsection{REFERENCES}

2.1 DWG H-1-462154, Fuel Encapsulation MK II Canister Assembly.

\subsection{RESPONSIBILITIES}

\subsection{Surveillance Systems Integration (SSI)}

Surveillance Systems Integration (SSI) shall be responsible for coordination, scheduling, performance and documentation of this test procedure. SSI will also be responsible for providing all hardware necessary to accomplish this activity.

\subsection{Test Witnesses}

Spent Nuclear Fuel Evaluations shall be responsible for providing any ancillary documentation or personnel required to complete this activity.

Test witnesses are responsible for verifying that organizational requirements are met throughout the testing and documentation sequences of the procedure.

\subsection{DOCUMENTATION}

\subsection{Test Records}

All personnel involved in the performance of this test shall fill out applicable sections of this test procedure. 


\subsection{Exceptions}

Exceptions by step number, and other notes shall be recorded in section 7 . This section must be dispositioned and signed off prior to final ATP approval. If no exceptions are encountered, this section shall so be noted and closed out with the required signatures. Errors noted during the performance of this test shall be corrected to facilitate test completion. Each correction shall be noted and listed in section 7.0 of this procedure.

\subsection{Test Exception Record}

Approval of the ATP results shall be accepted by SNF Evaluations as indicated by signature in Section 7.0.

\subsection{Qualifications}

Performance of this Acceptance Test Procedure serves to qualify the performers of this test also as the performers for the actual field activity.

\subsection{PREREQUISITES}

Note: The following steps are performed to characterize the Mark II canisters, sludge, and sludge displacement due to the presences of simulated fuel elements. The signal processor shall have current calibration status. The system shall be functionally tested per the following procedure. The following recorded data is intended to establish a baseline for engineering information purposes only. Caliper measurements have already been accomplished. The tolerance between the caliper measurements and the following averaged UT measurement is $\pm 2.54 \mathrm{~mm}(.1 \mathrm{in})$.

5.1 Measure the height of each Mark II canister barrel from the floor to the top lip. The height of the first barrel is

$1^{\text {st }}$ Mark II Canister Barrel Height

and the height of the second barrel is

$2^{\text {nd }}$ Mark II Canister Barrel Height

5.2 Measure the length of the sludge depth measurement device from the tip of the UT transducer to the center of the cross members. The length of the probe is

Probe length

Note: Per reference 2.1 the nominal thickness of the bottom plate of the Mark II canister barrel is $0.158 \mathrm{~m}(0.25 \mathrm{in}$.).

5.3 On the 305 Building dry floor, insert 7 simulated fuel elements and water into the $1^{\text {st }}$ Mark II canister barrel. 
5.4 Insert the ultrasonic probe, by hand, into the canister and measure the distance from the probe to the bottom of the canister at the predetermined points. Record the UT probe measurement digitally displayed on the EPOCH II signal processor in Table 1. The thickness is determined by subtracting the length of the probe and measurement entered in Table 1 and the nominal thickness of the bottom plate from the overall height of the canister.

\section{Thickness $=$ height of canister - (length of probe + UT measurement + Bottom Plate Thickness)}

5.5 In the other Mark II canister barrel, add water and approximately $2.54 \mathrm{~cm}$ (1 inch) of sludge. Allow sufficient time for the sludge to settle in the bottom of the canister.

5.6 Insert the UT probe, by hand, into the canister barrel with the sludge and adjust the Epoch II to obtain the thickness of the sludge at the same set points as the first Mark II canister. Record the data in Table 2.

5.7 Determine the thickness of the sludge and compare it to the caliper measurements. Save the system set-up on the Epoch II as this configuration serves as the functional check for this system.

5.8 Add four (4) simulated fuel elements to the Mark II canister that contains the sludge. Allow sufficient time for the sludge to settle.

5.9 Insert the UT probe, by hand, into the canister. Move the probe to the predetermined set points then measure and record the UT data in Table 3.

5.10 Calculate the average thickness of the sludge and compare it to the caliper measurement.

5.11 Add three (3) more simulated fuel elements to the same Mark II canister barrel.

5.12 Insert the UT probe, by hand, into the canister at the predetermined set points. Measure and record the UT data in Table 4.

5.13 Calculate the thickness of the sludge and compare it to the caliper measurements.

\subsection{ACCEPTANCE TEST}

NOTE: The simulated fuel cells will shift during transport which will change the sludge/water interface. This interface change will cause the following measurements to deviate from the already recorded data. The following recorded data shall be averaged prior to comparison to the caliper measurements.

6.1 Lower the Mark II canister into the K-Basin mock-up pool. Allow sufficient time for the sludge to settle assuming the sludge was disturbed during transport.

6.2 Attached the UT probe to the stainless steel poles and lower the probe into the pool. 
6.3 Carefully lower the UT probe into the Mark II canister barrel that contains seven (7) simulated fuel element and no sludge. Using the saved system setup parameters, measure and record in Table 5 the same data points, if possible, taken in step 5.4 above.

6.4 Calculate the average thickness and compare the value with the values obtained in step 5.4 above.

6.5 Move the UT probe to the Mark II canister barrel with the sludge.

6.6 Insert the UT probe into the same set points as step 5.9. Measure and record the sludge thickness in Table 6.

6.7 Calculate the average thickness of the sludge and record the data in Table 6 .

6.8 SSI Test Engineer and SNF Evaluations shall verify, in Table 6, the sludge thickness is within $2.54 \mathrm{~mm}$ (.100 in.) of the caliper measurement. 
WHC-SD-SNF-ATP-018 Rev. 0

Page 8 of 15

\subsection{TEST EXECUTION DATA SHEETS}

DATE:

DOCUMENT NUMBER

SERIAL OR TEST NUMBER TITLE OF TEST: Barrel No. 1 (No Sludge, 7 Fuel Rods)

TEST PERFORMED BY:

TABLE 1

\begin{tabular}{|c|c|c|c|c|c|}
\hline TEST POINT & MEASUREMENT & $\begin{array}{l}\text { CALIPER } \\
\text { MEASUREMENT }\end{array}$ & DIFFERENCE & $\begin{array}{l}\text { AVERAGE UT } \\
\text { MEASUREMENT }\end{array}$ & ACCEPT/REJECT \\
\hline & & & & & \\
\hline & & & & & \\
\hline & & & & & \\
\hline & & & & & \\
\hline & & & & & \\
\hline & & & & & \\
\hline & & & & & \\
\hline & & & & & \\
\hline & & & & & \\
\hline & & & & & \\
\hline & & & & & \\
\hline & & & & . & \\
\hline & & & & & \\
\hline & & & & & \\
\hline
\end{tabular}

TEST WITNESSES:

Cognizant Engineer

Date

SNF Evaluations

Date 
DATE:

SERIAL OR TEST NUMBER TEST PERFORMED BY:
DOCUMENT NUMBER

TITLE OF TEST: Barrel No.2 (With Sludge. No Fuel)

TABLE 2

\begin{tabular}{|c|c|c|c|c|c|}
\hline TEST POINT & MEASUREMENT & $\begin{array}{l}\text { CALIPER } \\
\text { MEASUREMENT }\end{array}$ & DIFFERENCE & $\begin{array}{l}\text { AVERAGE UT } \\
\text { MEASUREMENT }\end{array}$ & ACCEPT/REJECT \\
\hline & & & & & \\
\hline & & & & & \\
\hline & & & & & \\
\hline & & & & & \\
\hline & & & & & \\
\hline & & & & & \\
\hline & & & & & \\
\hline & & & & & \\
\hline & & & & & \\
\hline & & & & & \\
\hline & & & & & \\
\hline & & & & & \\
\hline & & & & & \\
\hline & & & & & \\
\hline
\end{tabular}

TEST WITNESSES:

Cognizant Engineer

Date

SNF Evaluations

Date 
DATE:

SERIAL OR TEST NUMBER

TEST PERFORMED BY:
DOCUMENT NUMBER

TITLE OF TEST: Barrel No. 2 (Sludge \& 4 Fuel Rods)

TABLE 3

\begin{tabular}{|c|c|c|c|c|c|}
\hline TEST POINT & MEASUREMENT & $\begin{array}{c}\text { CALIPER } \\
\text { MEASUREMENT }\end{array}$ & DLFFERENCE & $\begin{array}{l}\text { AVERAGE UT } \\
\text { MEASUREMENT }\end{array}$ & ACCEPT/REJECT \\
\hline & & & & & \\
\hline & & & & & \\
\hline & & & & & \\
\hline & & & & & \\
\hline & & & & & \\
\hline & & & & & \\
\hline & & & & & \\
\hline & & & & & \\
\hline & & & & & \\
\hline & & & & & \\
\hline & & & & & \\
\hline & & & & & \\
\hline & & & & & \\
\hline & & & & & \\
\hline
\end{tabular}

TEST WITNESSES:

Cognizant Engineer

Date

SNF Evaluations

Date 
DATE:

SERIAL OR TEST NUMBER

TEST PERFORMED BY:
DOCUMENT NUMBER

TITLE OF TEST: Barrel No.2 (Sludge and 7 Fuel Rods)

TABLE 4

\begin{tabular}{|c|c|c|c|c|c|}
\hline TEST POINT & MEASUREMENT & $\begin{array}{l}\text { CALPER } \\
\text { MEASUREMENT }\end{array}$ & DIFFERENCE & $\begin{array}{l}\text { AVERAGE UT } \\
\text { MEASUREMENT }\end{array}$ & ACCEPT/REIECT \\
\hline & & & & & \\
\hline & & & & & \\
\hline & & & & & \\
\hline & & & & & \\
\hline & & & & & \\
\hline & & & & & \\
\hline & & & & & \\
\hline & & & & & \\
\hline & & & & & \\
\hline & & & & & \\
\hline & & & & & \\
\hline & & & & & \\
\hline & & & & & \\
\hline & & & & & \\
\hline
\end{tabular}

TEST WITNESSES:

Cognizant Engineer

Date

SNF Evaluations

Date 
WHC-SD-SNF-ATP-018 Rev. 0

Page 12 of 15

DATE:

SERIAL OR TEST NUMBER

TEST PERFORMED BY:
DOCUMENT NUMBER TITLE OF TEST: Barrel No. 1 (No Sludge, 7 Fuel Rods)

TABLE 5

\begin{tabular}{|c|c|c|c|c|c|}
\hline TEST POINT & MEASUREMENT & $\begin{array}{l}\text { CALIPER } \\
\text { MEASUREMENT }\end{array}$ & DIFFERENCE & $\begin{array}{l}\text { AVERAGE UT } \\
\text { MEASUREMENT }\end{array}$ & ACCEPT/REJECT \\
\hline & & & & & \\
\hline & & & & & \\
\hline & & & & & \\
\hline & & & & & \\
\hline & & & & & \\
\hline & & & & & \\
\hline & & & & & \\
\hline & & & & & \\
\hline & & & & & \\
\hline & & & & & \\
\hline & & & & & \\
\hline & & & & & \\
\hline & & & & & \\
\hline & & & & & \\
\hline
\end{tabular}

TEST WITNESSES:

Cognizant Engineer

SNF Evaluations
Date

Date 
DATE:

SERIAL OR TEST NUMBER TEST PERFORMED BY:
DOCUMENT NUMBER TITLE OF TEST: Barrel No. 2 (Sludge, 7 Fuel Rods)

TABLE 6

\begin{tabular}{|c|c|c|c|c|c|}
\hline TEST POINT & $\begin{array}{l}\text { UT } \\
\text { MEASUREMENT }\end{array}$ & $\begin{array}{l}\text { CALIPER } \\
\text { MEASUUREMENT }\end{array}$ & DIFFERENCE & $\begin{array}{l}\text { AVERAGE UT } \\
\text { MEASUREMENT }\end{array}$ & ACCEPT/REJECT \\
\hline & & & & & \\
\hline & & & & & \\
\hline & & & & & \\
\hline & & & & & \\
\hline & & & & & \\
\hline & & & & & \\
\hline & & & & & \\
\hline & & & & & \\
\hline & & & & & \\
\hline & & & & & \\
\hline & & & & & \\
\hline & & & & & \\
\hline & & & & & \\
\hline
\end{tabular}

TEST WITNESSES:

Cognizant Engineer

Date

SNF Evaluations

Date 


\subsection{TEST EXECUTION RECORD}

\begin{tabular}{|c|l|l|}
\hline Reference Section & Accept/Reject & Remarks \\
\hline 6.1 & & \\
\hline 6.2 & & \\
\hline 6.3 & & \\
\hline 6.4 & & \\
\hline 6.5 & & \\
\hline 6.6 & & \\
\hline 6.7 & & \\
\hline 6.8 & & \\
\hline
\end{tabular}

\section{TEST WITNESSES}

SSI Test Engineer/Date

\section{SNF Evaluations/Date}

\subsection{FINAL ACCEPTANCE}

Testing per this procedure has been completed satisfactorily and the Sludge Measurement Device is ready for be placed into service.

SNF Evaluations Date


WHC-SD-SNF-ATP-018 Rev. 0

Page 15 of 15

Figure 1. UT Measurement Locations



